\title{
Household Decision-Making in Malaysia: The Ethnic Dimension
}

\author{
Selamah Abdullah Yusof
}

Accepted: 4 October 2014/Published online: 11 October 2014

(C) Springer Science+Business Media Dordrecht 2014

\begin{abstract}
Household financial decision-making process is an important issue as it has shown to have implications on key development outcomes such as child health and education, nutrition, expenditure, and allocation of labor. Women's ability to have control over household finances and decisions also reflects, to some extent, their level of empowerment. This study focuses on the effect of ethnicity on decision making in a household. There is relatively limited research in this area and data obtained from households in Malaysia, a multi-ethnic and multi-cultural country, provides an opportunity for an in-depth examination of the ethnic dimension. The data is obtained from a random survey of 672 Malaysian urban households of which the selection of sample was strictly determined by the Department of Statistics Malaysia to ensure randomness. The findings show that there are differences across households of different ethnicity. Chinese households are found to be more traditional and patriarchal where decisions on household financial matters are more husband-dominated. Education contributes positively in giving women more control over household finances and decision-making. The results of the study highlight the importance of ethnicity in determining the level of household bargaining and decisionmaking power which has implications on strategies in marketing as well as national policies. Thus, any substantive and policy inferences in relations to women's empowerment must take into account the socio-cultural aspects, rather than based on overall national level analyses. The finding that education plays a significant role in empowering women is a positive outcome. With more Malaysian women attaining higher levels of education and becoming part of the workforce, their level of empowerment and wellbeing will improve and consequently provide a positive impact on key development outcomes of the country.
\end{abstract}

Keywords Women $\cdot$ Malaysia $\cdot$ Malay $\cdot$ Chinese $\cdot$ Education $\cdot$ Bargaining power

\footnotetext{
S. A. Yusof $(\square)$

Department of Economics, International Islamic University Malaysia, Jalan Gombak,

53100 Kuala Lumpur, Malaysia

e-mail: selamah@iium.edu.my
} 


\section{Introduction}

The study of financial decision-making processes within a household is important as it is argued that they have implications on key development outcomes. Empirical studies have shown that decisions and outcomes in a household such as child health and education, nutrition, and expenditures for different goods and services depend strongly on whether its income is controlled by the husband or the wife (see Thomas 1994; Lundberg et al. 1997; Phipps and Burton 1998; Duflo 2003). Decisions within a household that are influenced by the women's bargaining power also impact household production, such as allocation of labor across various activities, including household chores, agricultural work, and wage work (Doss 2011). Studies such as OlaOlorun and Hindin (2014), Bankole (1995), Schultz (1990) and Klawon and Tiefenthaler (2001) find that women's bargaining power in a household affects fertility decisions, while Story and Burgard (2012) indicate that it affects utilization of maternal health services. Intra-household decision making has also been shown to have an influence on savings (Seguino and Floro 2003). Qian (2008) reports that female income as a share of total household income in Chinese rural households has significant positive impact on the survival rates for girls, and on the educational attainment of children.

However, based on their theoretical model, Doepke and Tertilt (2014) demonstrate that targeting transfers to women may hurt growth in economies where physical capital accumulation is the main engine of growth. It makes good economic policy if the economy relies mostly on human capital. Nonetheless, empowering women is a worthy cause in its own right as the role women play in decision making and their bargaining power in the household impact their own well-being. Women's ability to make choices related to their daily life which includes control over household finances and decision-making reflects their level of empowerment (Boateng et al. 2014).

There are various factors that are related to women's bargaining power such as wealth (Gummerson and Schneider 2013) and income (Lee and Beatty 2002; Burgoyne and Morison 1997; Laurie and Rose 1994; Goode et al. 1998; Pahl 1995, 2000; Vogler and Pahl 1993, 1994; Yilmazer and Lyons 2010; Malone et al. 2010; Carlsson et al. 2013). AlMamun et al. (2014) shows that microcredit programs to increase the income of poor women in urban areas in Malaysia contribute positively to their role in household decision making and empowerment. Education, employment and age are also found to be associated with the level of decision-making power (Jianakoplos and Bernasek 2008; Boateng et al. 2014; Sinha 2012; Hou and Ma 2013). Other studies have shown that variations in family structure result in differences in household decision making (McConocha et al. 1993; Razzouk et al. 2007; Woolley 2003; Yusof and Duasa 2010). Ngenzebuke et al. (2014) finds that kinship network characteristics are significant factors of within household decision-making power. In addition, ethnicity and culture also plays a significant role as studies have shown that there are differences in household decision-making process across ethnic and cultural groups (Ford et al. 1995; Stafford and Ganesh 1996; Xia et al. 2006; Kritz and Makinwa-Adebusoye 1999).

Despite the considerable research on household financial decision making, there is relatively limited number of studies that examine the effect of culture or ethnicity on decision-making behavior. This paper contributes to the cross-ethnic and cultural literature by examining women's bargaining power and decision-making of households of different ethnic background but living in the same social setting. It differs from those of Ford et al. (1995) and Xia et al. (2006) as they make comparisons between groups living in different countries. Ford et al. (1995) compares samples from People's Republic of China and the 
United States, while Xia et al. (2006) investigates Singaporean family purchase decisionmaking process with that of American families. Although Kritz and Makinwa-Adebusoye (1999) look at ethnic differences for a particular country, specifically Africa, each of the ethnic groups was sampled from different regions of the country. The study by Stafford and Ganesh (1996) does examine differences between US Americans and Indian Tamil US immigrants living in the same social setting, apart from making comparison with Indian Tamils living in India. However, their study is specifically focusing on the decisionmaking process for some specific services and on issues of acculturation and assimilation. In addition, their sample consists of only female head of households.

This study examines ethnic differences in financial household decision making in Malaysia which is a multi-cultural and multi-ethnic country. It is made up of three distinct main ethnic groups which are Malay (54.6\%), Chinese (24.6\%) and Indian (7.3\%). ${ }^{1}$ All three ethnic groups live in the same communities, although Malay are slightly disproportionately more in non-urban areas while Chinese and Indian are relatively more in urban areas. $^{2}$ There are some differences in the structure of the household across ethnic groups. In 2010, 67.5\% of Malay households are made up of nuclear families and $18.2 \%$ are extended families. This is in comparison to Chinese and Indian households of which 62.2 and $63.5 \%$ comprised of nuclear families and 20.7 and $24.2 \%$ of extended families, respectively. The mean monthly household income in 2012 of Bumiputera (of which majority are Malay) is RM4,457, which is lower than that of Chinese of RM6,366, and Indian of RM5,233. ${ }^{3}$ The mean monthly salaries and wages in 2012 for Malay is RM1,990 and the gender wage gap is $5.7 \%$ in favor of men. Chinese and Indian, on the other hand, earned an average of RM2,331 and RM1,903, with a male-female wage gap of 12.5 and $20.8 \%$, respectively. ${ }^{4}$

Malaysia is also experiencing structural changes with respect to women in the labor force. Women labor force participation rate has been rising in recent years, from $45.7 \%$ in 2008 to $49.5 \%$ in $2012 .^{5}$ There are also distinct differences in the labor force ratio of men to women across educational attainment. In 2011, men made up $69.9 \%$ of the labor force with primary education. The percentage drops to $67.5 \%$ for the group with highest attainment of secondary education, and a smaller percentage still of $53.5 \%$ for those with tertiary education. ${ }^{6}$ The differences in the characteristics of the households and the dynamics in the labor force may impact the role women play in households. Data on Malaysian households offer an interesting opportunity for a more in-depth examination of household decision-making and women bargaining power, and differences across ethnicity and culture.

\footnotetext{
${ }^{1}$ http://www.statistics.gov.my/portal/download_Population/files/census2010/Taburan_Penduduk_dan_ Ciriciri_Asas_Demografi.pdf. Retrieved on 19 May 2014.

${ }^{2}$ Ibid. Population of Malay in urban areas is $50.8 \%$, Chinese $31.3 \%$, and Indian $9.1 \%$.

${ }^{3} \mathrm{http} / / / \mathrm{www} \cdot$ statistics.gov.my/portal/index.php?option=com_content\&view=article\&id=1640\&Itemid= $169 \&$ lang=en. Retrieved on 19 May 2014

4 http://www.statistics.gov.my/portal/download_Labour/files/BPTMS/Salaries_and_Wages_Survey_Report_ 2012_11092013.pdf. Retrieved on 19 May 2014.

5 Labour Force Survey Report Malaysia 2012, http://www.statistics.gov.my/portal/download_Labour/files/ labour_force/Labour_Force_Survey_Report_Malaysia_2012.pdf.

6 Ibid.
} 


\section{Sample and Measure}

\subsection{The Sample}

The data that is used in this study is obtained from a random survey conducted in June to October, 2013. The selection of sample was restricted to households in Klang Valley ${ }^{7}$ to represent the urban population of Malaysia. To ensure randomness and representativeness, the selection of the sample was strictly determined by the Department of Statistic (DOS) Malaysia using its 2010 Census sampling frame. Klang Valley comprises of five administrative districts and each district is divided into enumeration blocks, and each enumeration block consists of 80-120 living quarters or households. Based on a margin of error of 0.06 , an expected response rate of $80 \%$, and design effect of $2,{ }^{8}$ the number of enumeration blocks from each administrative district was determined proportionately. From each selected enumeration block, households were randomly selected, resulting in a sample size of 672 households.

Four sets of identical questionnaires were prepared in three different languages-Malay, English, Chinese/Malay and Chinese/English - to cater to the different ethnic groups in Malaysia. An adult male or female of each household was either interviewed, or given the questionnaire for them to complete on their own. Since this study focuses on decision making within a household, in particular of husband and wife, the analysis is based only on the responses of those who were currently married at the time of the survey, which is about $69.5 \%$ of the total number of those who successfully participated in the survey.

\subsection{Measure of Women's Decision Making and Bargaining Power in a Household}

Empirical works to understand the bargaining process within households have used various indicators to measure women's bargaining power. These include share of income (Yusof and Duasa 2010), asset ownership (Panda and Agarwal 2005), education (Doss 2011). Some other studies utilize women's role in household decision-making to represent the bargaining power of women as in Allendorf (2007), Mabsout and van Staveren (2010) and Connelly et al. (2010) or women's autonomy to travel and make independent decisions (Doss 2011) as a measure.

This study follows Allendorf (2007), Mabsout and van Staveren (2010) and Connelly et al. (2010) to measure women's decision-making power. Specifically, it is based on a question in the survey which asks respondents to describe the way financial matters are decided in their household and provides six possible responses: (1) "I leave it to my spouse/partner to decide on all financial matters"; (2) "My spouse/partner has more influence than me on financial decisions"; (3) "My spouse/partner and I have equal influence on financial decisions"; (4) "I have more influence on financial decisions than my spouse/partner does"; (5) "My spouse/partner leaves all financial decisions to me"; and

\footnotetext{
7 Klang Valley is an area in Malaysia comprising of its capital Kuala Lumpur and its suburbs, and adjoining cities and towns in the state of Selangor.

8 As cluster random sampling is utilized, the sample is not as varied as it would be in a simple random sampling. The selection of an additional member from the same cluster adds less information than would a completely independent selection. The design effect measures this loss of effectiveness, which is computed as the ratio of the actual variance under the sample method actually used to the variance computed under the assumption of simple random sampling. Thus, a design effect of two implies that the sample variance is two times bigger than it would be if the survey were based on the same sample size but selected using simple random sampling.
} 
(6) "I do not have a partner/None of the above statement applies to my situation". Three married respondents who chose option (6) and two who did not respond to this question were omitted from the analysis. For others, the degree of household decision-making power is determined by the extent of influence the respondents have on the financial decisions of the household, and they are assigned the values of 1-5 accordingly.

\section{Findings}

\subsection{The Sample}

The sample households, as presented in Table 1, are made up $34.8 \%$ females and $65.2 \%$ males, and $56.4 \%$ Malay, $28.5 \%$ Chinese, $12.2 \%$ Indian and $2.8 \%$ "other", which are somewhat comparable to the population percentages. ${ }^{9}$ As expected, majority of the male respondents were the head of the household, compared to a much smaller percentage $(11 \%)$ of the female respondents. However, a larger fraction of women (34\%) were the main wage earners (the person with the highest monthly income in the household). Women also have higher levels of education relative to men but over $30 \%$ of them were not working, compared to $10 \%$ of men. Men also earned relatively higher levels of incomes and own more wealth. In this sample, women are more in the younger age groups compared to men.

\subsection{Household Decision Making and Ethnicity}

Table 2 reports the decision-making process in a household across ethnic groups. ${ }^{10}$ It can be seen that for Malay households, decisions on financial matters are influenced somewhat equally by the husband and wife. The situation is different in Chinese households were men seem to have more influence that the women. The results for Indian households are rather peculiar where although $38 \%$ of the women stated that they leave the decisions to their husbands, another $23 \%$ indicated that their husbands leave all the decisions to them. The latter is consistent with that reported by men in which almost $27 \%$ leave it to their wives, another $15 \%$ said that their spouse had more influence, and only $<8 \%$ have total influence on the household financial decisions. Nevertheless, it should be noted that the number of respondents for Indians is small.

For a more robust analysis, $t$ tests on differences of means are conducted to determine if these differences are significant. The mean score for the Chinese women is significantly lower than that for Chinese men ${ }^{11}$ (see Table 3). This implies that Chinese men have more influence on household financial decision making than the women. For Malay and Indian households, the results indicate no significance difference. Thus, in these households, generally men and women have equal influence in decisions pertaining to financial matters. Within gender, Chinese men's extent of influence is significantly higher than that of Malay

\footnotetext{
9 The population estimates for 2011 are $54.65 \%$ Malay, $24.33 \%$ Chinese, $7.30 \%$ Indians and $13.73 \%$ others, out of the total Malaysian citizens population (Malaysia 2011). Klang Valley Malaysian population in 2010 was made up of $49.56 \%$ Malay, $36.72 \%$ Chinese, $11.59 \%$ Indian and $2.12 \%$ others http://www. statistics.gov.my/portal/index.php?option=com_content\&view=article\&id=1354\&Itemid=111\&lang=en). Retrieved on March 22, 2013.

10 All the analyses are focused on the three main ethnic groups-Malay, Chinese and Indian. The number of respondents for "other" category is too small for a worthwhile analysis.

11 Significant at $1 \%$ level.
} 
Table 1 Sample description of respondents

\begin{tabular}{|c|c|c|c|}
\hline & Female & Male & Total \\
\hline \multicolumn{4}{|l|}{ Household position } \\
\hline Head & $12(10.81)$ & $163(79.51)$ & $175(55.38)$ \\
\hline Other & 99 (89.19) & $42(20.49)$ & $141(44.62)$ \\
\hline \multicolumn{4}{|l|}{ Main earner } \\
\hline Yes & $37(33.64)$ & $171(82.21)$ & $208(65.41)$ \\
\hline No & $73(66.36)$ & $37(17.79)$ & $110(34.59)$ \\
\hline \multicolumn{4}{|l|}{ Education } \\
\hline$\leq$ Primary & $7(6.31)$ & $19(9.13)$ & $26(8.15)$ \\
\hline Secondary & $40(36.04)$ & $83(39.90)$ & $123(38.56)$ \\
\hline Diploma & $30(27.03)$ & $44(21.15)$ & $74(23.20)$ \\
\hline$\geq$ Bachelor & $34(30.63)$ & $62(29.81)$ & $96(30.09)$ \\
\hline \multicolumn{4}{|l|}{ Ethnicity } \\
\hline Malay & $62(55.86)$ & $118(56.73)$ & $180(56.43)$ \\
\hline Chinese & $32(28.83)$ & $59(28.37)$ & $91(28.53)$ \\
\hline Indian & $13(11.71)$ & $26(12.50)$ & $39(12.23)$ \\
\hline Other & $4(3.60)$ & $5(2.40)$ & $9(2.82)$ \\
\hline \multicolumn{4}{|l|}{ Age } \\
\hline$\leq 25$ & $6(5.41)$ & $9(4.57)$ & $15(4.87)$ \\
\hline $26-35$ & $49(44.14)$ & $47(23.86)$ & $96(31.17)$ \\
\hline $36-50$ & $43(38.74)$ & $83(42.13)$ & $126(40.91)$ \\
\hline $51-60$ & $12(10.81)$ & $46(23.35)$ & $58(18.83)$ \\
\hline $61+$ & $1(0.90)$ & $12(6.09)$ & $13(4.22)$ \\
\hline \multicolumn{4}{|l|}{ Work status } \\
\hline Employed & $57(51.35)$ & $104(50.00)$ & $161(50.47)$ \\
\hline Own business/freelance & $19(17.12)$ & $83(39.90)$ & $102(31.97)$ \\
\hline Not working & $35(31.53)$ & $21(10.10)$ & $56(17.55)$ \\
\hline \multicolumn{4}{|l|}{ Monthly income (in RM) } \\
\hline$<1,500$ & $29(26.13)$ & $26(12.5)$ & $55(17.24)$ \\
\hline $1,500-2,500$ & $31(27.93)$ & $44(21.15)$ & $75(23.51)$ \\
\hline $2,500-4,000$ & $28(25.23)$ & $57(27.40)$ & $85(26.65)$ \\
\hline $4,000+$ & $23(20.72)$ & $81(38.94)$ & $104(32.60)$ \\
\hline \multicolumn{4}{|l|}{ Wealth level (in RM) } \\
\hline$<5,000$ & $24(21.62)$ & $25(12.08)$ & $49(15.41)$ \\
\hline $5,000-<40,000$ & $28(25.23)$ & $45(21.74)$ & $73(22.96)$ \\
\hline $40,000-<100,000$ & $18(16.22)$ & $45(21.74)$ & $63(19.81)$ \\
\hline $100,000-<300,000$ & $28(25.23)$ & $40(19.32)$ & $68(21.38)$ \\
\hline $300,000+$ & $13(11.71)$ & $52(25.12)$ & $65(20.44)$ \\
\hline
\end{tabular}

percentage

or Indian men. ${ }^{12}$ However, there is no significant difference among women of the three ethnic groups.

Are the differences in decision making found in Chinese households, and between Chinese men and others due to their ethnicity, or due to factors such as income, education

12 Significant at $5 \%$ level. 


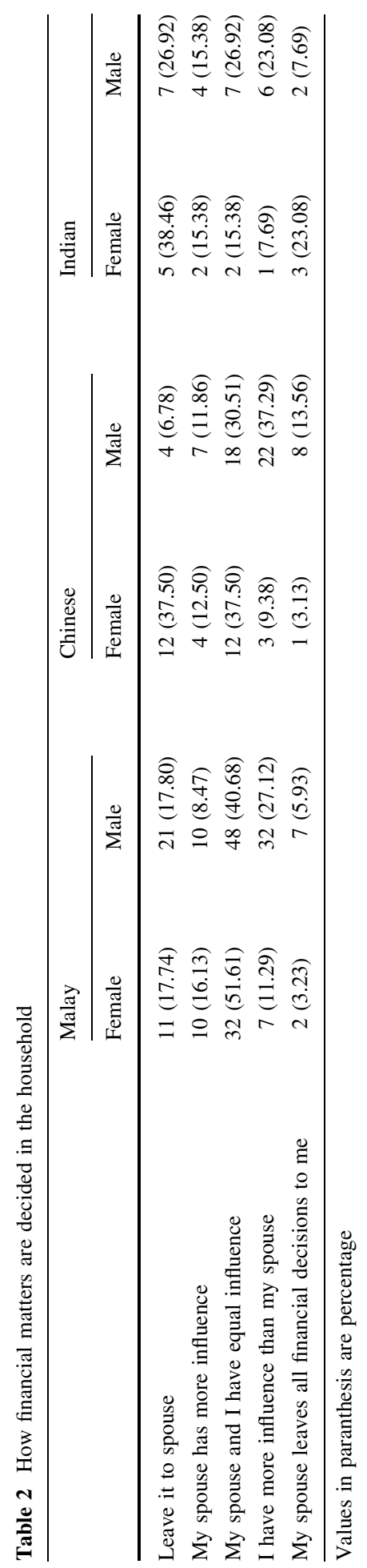


Table 3 Extent of influence on financial decision making

The score is based on a scale of 1-5 where 1: no influence at all; 5: has total influence

\begin{tabular}{lcccccccc}
\hline & Malay & & & \multicolumn{2}{l}{ Chinese } & & & \multicolumn{2}{l}{ Indian } & \\
\cline { 2 - 3 } \cline { 8 - 9 } & Female & Male & & Female & Male & & Female & Male \\
\hline Mean & 2.66 & 2.95 & 2.28 & 3.39 & & 2.62 & 2.69 \\
$\mathrm{SD}$ & 1.01 & 1.15 & & 1.17 & 1.08 & & 1.66 & 1.32 \\
$\mathrm{~N}$ & 62 & 118 & 32 & 59 & & 13 & 26 \\
\hline
\end{tabular}

level and age, as found by previous studies? To determine the effects of, and to control for these factors, ordinal regression analysis is conducted. The dependent variable of household decision making power is assigned the value of 1 for the response of "Leave it to spouse"; 2 for "My spouse has more influence"; 3 for "My spouse and I have equal influence"; 5 for "I have more influence than my spouse"; and 5 for "My spouse leaves all financial decisions to me". The results are given in Table 4.

A regression on all respondents shows that the main wage earner in a household has more influence on financial decision making in a household. Regressions on samples according to gender and ethnic groups reveal that this factor applies to Malay and Indian households, but not to those of Chinese. It is also found that for the whole sample, men have more influence in decision making, compared to women. However, further regressions indicate that the greater influence of males applies to Chinese households, but not for the other two ethnic groups. The impact of wealth is different between Malays and Chinese. Malays with higher levels of wealth have more decision-making power, but interestingly, the opposite applies to the Chinese. Additionally, for Chinese households, there is a weak positive association between income and level of influence in decision making. In Indian households, older respondents have somewhat (significant at $10 \%$ ) less decisionmaking power than their younger counterpart.

Among the women, education is positively related to decision-making power. Malay women have higher levels of influence in household financial matters compared to Chinese women. Factors such as income and wealth do not play a significant role in the extent of influence in decisions related to household financial matters among women.

\section{Discussion and Conclusion}

This study uses data from a recent random survey of households to examine decisionmaking power of married men and women and differences across the three ethnic groups in Malaysia. The results indicate that there are differences across ethnic groups, even after controlling for other factors. Chinese households are found to be more traditional and patriarchal, compared to others, where decisions on household financial matters are more husband-dominated. The impact of wealth on decision-making power is also different for households of different ethnicity. For women, the level of education contributes significantly in giving them more control over household finances and decision-making.

If empowerment is reflected in the ability to make choices related to their daily life which includes control over household finances and decision-making (Boateng et al. 2014), then Chinese women have a lower level of empowerment compared to Malay women. As has been stated earlier, Chinese households have a much higher mean income than other households. In addition, Chinese also attain higher salaries and wages, on average, 
Table 4 Ordinal regressions of household decision making

\begin{tabular}{|c|c|c|c|c|c|c|}
\hline & All & Female & Male & Malay & Chinese & Indian \\
\hline Main earner & $0.889 * * *$ & 0.310 & $0.774 * *$ & 0.295 & 0.697 & $2.375^{* *}$ \\
\hline Age & -0.005 & 0.002 & 0.005 & -0.006 & 0.032 & $-0.099 *$ \\
\hline Education & 0.021 & $0.899 * * *$ & -0.072 & $0.285^{*}$ & 0.089 & -0.658 \\
\hline Income & 0.022 & 0.029 & -0.006 & -0.006 & $0.172 *$ & 0.309 \\
\hline Wealth & $0.083 * *$ & 0.107 & 0.045 & $0.155 * *$ & $-0.357 * * *$ & 0.102 \\
\hline Male & $0.466^{*}$ & & & 0.571 & $1.836 * * *$ & 1.191 \\
\hline Chinese & -0.195 & $-1.257 * *$ & 0.262 & & & \\
\hline Indian & $-0.900 * * *$ & -0.995 & -0.568 & & & \\
\hline Cox and Snell $\mathrm{R}^{2}$ & 0.126 & 0.274 & 0.058 & 0.125 & 0.231 & 0.440 \\
\hline Nagelkerke $\mathrm{R}^{2}$ & 0.133 & 0.292 & 0.061 & 0.133 & 0.243 & 0.461 \\
\hline McFadden $\mathrm{R}^{2}$ & 0.046 & 0.114 & 0.020 & 0.048 & 0.087 & 0.186 \\
\hline
\end{tabular}

$*, * *, * * *$ Significant at 10,5 , and $1 \%$, respectively

compared to others. The gender wage gap in favor of men is more than twice that of Malays. Thus, generally, the difference in income between a Chinese husband and wife is large, compared to a Malay couple. Due to this, the balance of power may tip towards the husband in a Chinese household.

The findings of the study highlight the influence of ethnicity in women's bargaining power and household financial decision making. Several implications can be derived from this study. Firstly, the findings would be useful to marketers in designing their marketing strategies accordingly by taking into account the ethnic dimension. In particular, Chinese men can be the optimal target rather than their spouse as they are more likely to be the decision makers in the household. On the other hand, for the Malay and Indian, promotional campaigns can be directed at either the men or women, or both. Secondly, with more women attaining higher levels of education and thus leading to more power in decision making in a household, it is imperative for them to have good financial literacy to be able to manage the household finances adequately. More opportunities and easy access to such training must be provided to women, and men, to ensure that wise and proper decisions are made for their household economic security and stability.

With regards to the national policies of the country, the existence of differences across ethnic groups indicates that socio-cultural aspects must be taken into account to ensure that correct substantive and policy inferences can be drawn, rather than based on overall national level analyses. While specific strategies may be targeted for certain ethnic groups, for example, programs to increase the wealth of poor Malay women to empower them, these initiatives must be transparent and the objectives must be clearly defined. This is crucial for a multi-ethnic and multi-cultural country like Malaysia, so that these policies are not seen as discriminatory by other groups, to safeguard the national and social stability of the country.

The finding that education level plays a significant role in empowering women is a positive outcome. Women should be further encouraged to pursue higher education as it contributes significantly to their wellbeing. Women having more power in decision-making power in a household would provide a positive impact on key development outcomes of the country. 
Acknowledgments This research was supported by the Exploratory Research Grant Scheme of the Ministry of Education Malaysia.

\section{References}

Allendorf, K. (2007). Do women's land rights promote empowerment and child health in Nepal? World Development, 35(11), 1975-1988.

Al-Mamun, A., Wahab, S. A., Mazumder, M. N. S., \& Su, Z. (2014). Empirical investigation on the impact of microcredit on women empowerment in urban Peninsular Malaysia. Journal of Developing Areas, 48(2), 287-306.

Bankole, A. (1995). Desired fertility and fertility behavior among the Yoruba of Nigeria: A study of couple preferences and subsequent fertility. Population Studies, 49(2), 317-328.

Boateng, G. O., Kuuire, V. Z., Ung, M., Amoyaw, J. A., Armah, F. A., \& Luginaah, I. (2014). Women's empowerment in the context of Millennium Development Goal 3: A case study of married women in Ghana. Social Indicator Research, 115, 137-158.

Burgoyne, C., \& Morison, V. (1997). Money in remarriage: Keeping things simple-and separate. The Sociological Review, 45, 363-395.

Carlsson, F., Martinsson, P., Qin, P., \& Sutter, M. (2013). The influence of spouses on household decision making under risk: An experiment in rural China. Experimental Economics, 16, 383-401.

Connelly, R., Roberts, K., \& Zheng, Z. (2010). The impact of circular migration on the position of married women in rural China. Feminist Economics, 16(1), 3-41.

Doepke, M., \& Tertilt, M. (2014). Does female empowerment promote economic development? NBER Working Paper No. 19888.

Doss, C. (2011). Intrahousehold bargaining and resource allocation in developing countries. World Development Report 2012: Gender equality and development, Background paper.

Duflo, E. (2003). Grandmothers and granddaughters: Old-age pensions and intrahousehold allocation in South Africa. World Bank Economic Review, 17(1), 1-25.

Ford, J. B., LaTour, M. S., \& Henthorne, T. L. (1995). Perception of marital roles in purchase decision processes: A cross-cultural study. Journal of the Academy of Marketing Science, 23(2), 120-131.

Goode, J., Callender, C., \& Lister, R. (1998). Purse or wallet? Gender inequalities and income distribution within families on benefits. London: Policy Studies Institute.

Gummerson, E., \& Schneider, D. (2013). Eat, drink, man, woman: Gender, income share and household expenditure in South Africa. Social Forces, 91(3), 813-836.

Hou, X., \& Ma, Ning. (2013). The effect of women's decision-making power on maternal health services uptake: Evidence from Pakistan. Health Policy and Planning, 28(2), 176-184.

Jianakoplos, N. A., \& Bernasek, A. (2008). Family financial risk taking when the wife earns more. Journal of Family and Economic Issues, 29, 289-306.

Klawon, E., \& Tiefenthaler, J. (2001). Bargaining over family size: The determinants of fertility in Brazil. Population Research and Policy Review, 20, 423-440.

Kritz, M., \& Makinwa-Adebusoye, P. (1999). Determinants of women's decision-making authority in Nigeria: The ethnic dimension. Sociological Forum, 14(3), 399-424.

Laurie, H., \& Rose, D. (1994). Divisions and allocations within households. In N. Buck, J. Gershuny, D. Rose, \& J. Scott (Eds.), Changing households: The British household panel survey 1990-1992 (pp. 220-242). Colchester: University of Essex.

Lee, C. K. C., \& Beatty, S. E. (2002). Family structure and influence in family decision making. Journal of Consumer Marketing, 19(1), 24-41.

Lundberg, S., Pollak, R., \& Wales, T. (1997). Do husbands and wives pool their resources? Evidence from the United Kingdom child benefit. Journal of Human Resources, 32(3), 463-480.

Mabsout, R., \& van Staveren, I. (2010). Disentangling bargaining power from individual and household level to institutions: Evidence on women's position in Ethiopia. World Development, 38(5), $783-796$.

Malone, K., Stewart, S. D., Wilson, J., \& Korsching, P. F. (2010). Perceptions of financial well-being among American women in diverse families. Journal of Family and Economic Issues, 31(1), 63-81.

McConocha, D. M., Tully, S. A., \& Walther, C. H. (1993). Household money management: Recognizing nontraditional couples. The Journal of Consumer Affairs, 27(2), 258-283.

Ngenzebuke, R. L., Rock, B. D., \& Verwimp, P. (2014). The power of the family: kinship and intrahousehold decision-making in rural Burundi. Universite Libre de Bruxelles, Working Papers ECARES: ECARES 2014-29. 
OlaOlorun, F. M., \& Hindin, M. J. (2014). Having a say matters: Influence of decision-making power on contraceptive use among Nigerian women ages 35-49 years. PLoS One, 9(6), 1-7. doi:10.1371/journal. pone.0098702.

Pahl, J. (1995). His money, her money: Recent research on financial organization in marriage. Journal of Economic Psychology, 16, 361-376.

Pahl, J. (2000). Couples and their money: Patterns of accounting and accountability in the domestic economy. Accounting, Auditing \& Accountability Journal, 13(4), 502-517.

Panda, P., \& Agarwal, B. (2005). Marital violence, human development and women's property status in India. World Development, 33(5), 823-850.

Phipps, S., \& Burton, P. (1998). What's mine is yours? The influence of male and female incomes on patterns of household expenditures. Economica, 65, 599-613.

Qian, N. (2008). Missing women and the price of tea in China: The effect of sex-specific earnings on sex imbalance. The Quarterly Journal of Economics, 123(3), 1251-1285.

Razzouk, N., Seitz, V., \& Capo, K. P. (2007). A comparison of consumer decision-making behavior of married and cohabiting couples. Journal of Consumer Marketing, 24(5), 264-274.

Schultz, P. (1990). Testing the neoclassical model of family labor supply and fertility. Journal of Human Resources, 25, 599-634.

Seguino, S., \& Floro, M. S. (2003). Does gender have any effect on aggregate savings? An empirical analysis. International Review of Applied Economics, 17(2), 147-166.

Sinha, K. (2012). Endogenous, intra-household decision-making and its impact on the labor supply of couples in rural India. Asian Economic Journal, 26(2), 137-157.

Stafford, M. R., \& Ganesh, G. (1996). Perceived spousal influence in the service decision-making process: A cross cultural investigation. Journal of Applied Business Research, 12(4), 53-69.

Story, W. T., \& Burgard, S. A. (2012). Couples' reports of household decision-making and the utilization of maternal health services in Bangladesh. Social Science and Medicine, 75(12), 2403-2411.

Thomas, D. (1994). Like father, like son; like mother, like daughter: Parental resources and child height. Journal of Human Resources, 29(4), 950-988.

Vogler, C., \& Pahl, J. (1993). Social and economic change and the organization of money in marriage. Work, Employment \& Society, 7(1), 71-95.

Vogler, C., \& Pahl, J. (1994). Money, power and inequality within marriage. Sociological Review, 42(2), $263-288$.

Woolley, F. (2003). Control over money in marriage. In S. A. Grossbard-Schechtman (Ed.), Marriage and the economy. Cambridge: Cambridge University Press.

Xia, Y., Ahmed, Z. U., Ghingold, M., Hwa, N. K., Li, T. W., \& Ying, W. T. C. (2006). Spousal influence in Singaporean family purchase decision-making process: A cross-cultural comparison. Asia Pacific Journal of Marketing and Logistics, 18(3), 201-222.

Yilmazer, T., \& Lyons, A. C. (2010). Marriage and allocation of assets in women's defined contribution plans. Journal of Family and Economic Issues, 31(2), 121-137.

Yusof, S. A., \& Duasa, J. (2010). Household decision-making and expenditure patterns of married men and women in Malaysia. Journal of Family and Economic Issues, 31(3), 371-381. 